\title{
Natural State Modeling of Singapore Geothermal Reservoir
}

\author{
Hendrik Tjiawi, Andrew C. Palmer, and Grahame J. H. Oliver
}

\begin{abstract}
The existence of hot springs coupled with the apparent anomalous high heat flow has sparked interest in the potential for geothermal development in Singapore. This geothermal resource may be potentially significant and could be exploited through Engineered Geothermal System (EGS) technology, i.e. a method to create artificial permeability at depth in granitic or sandstone formations as found under Singapore. The apparently ever-increasing fossil fuel price has made the cost of using the EGS technology more viable than it was in the past. Thus, to assess the resource, a numerical model for the geothermal reservoir has been constructed. Mass and heat flows in the system are simulated in 2D with AUTOUGH2.2, and the graphical interface processed through MULGRAPH2.2. Natural state calibration was performed to match both the observed and the expected groundwater profile, and also to match the hot water upflow at the Sembawang hot spring, with simulated flowrate matching the hot spring natural flowrate. The simulation gives an encouraging result of $125-150{ }^{\circ} \mathrm{C}$ hot water at depth $1.25-2.75 \mathrm{~km}$.
\end{abstract}

Keywords: Singapore, geothermal, reservoir, engineering, simulation

\section{INTRODUCTION}

G eothermal resource is commonly utilized in active volcanic regions, such as Iceland, Indonesia, New Zealand and

Philippines. In Singapore, though, there is no indication of recent volcanic activity, and so geothermal development has been overlooked. The recent advancement of Enhanced/Engineered Geothermal System (EGS) technology, the existence of hot springs and also the high heat flow have made it possible for geothermal development in Singapore (see [1, 2]). Oliver proposed a concept utilizing the EGS method to tap heat from the hot rock at a certain depth (e.g. $150{ }^{\circ} \mathrm{C}$ at $2 \mathrm{~km}$ depth). Possible applications of the geothermal resource include: electricity generation, which requires a water temperature of 150 ${ }^{\circ} \mathrm{C}$ or even more; district cooling using adsorption chiller, which requires $90{ }^{\circ} \mathrm{C}$ water [3]; and industrial process heating such as the heating in water desalination plant, requiring $60-85^{\circ} \mathrm{C}$ water [4]; or even their combination to form a cascading application system.

To assess the geothermal resource, a computer model is developed. The model is useful to assist in pre-feasibility study, in estimation of resource size, depth, temperature, and in prediction for development scenarios, e.g. placement of wells, well capacity, and service life. This paper describes the development and numerical simulation of the Singapore geothermal reservoir model. The model has been calibrated as far as possible to match its natural state as we see it today, prior to exploitation.

\section{EXISTING DATA}

Below are parameters essential to construct a conceptual model prior to the numerical simulation.

\section{The heat flow}

Hall and Morley [5] plotted a heat flow map for South East Asia (Figure 1) based on point data from existing oil wells. The nearest oil well to Singapore is about $100 \mathrm{~km}$ away from the west coast. By interpolation of data points, the heat flow for Singapore can be estimated from the map as between 110 and $130 \mathrm{~mW} / \mathrm{m}^{2}$. This heat flow is about double of the mean continental heat flow of earth, i.e. $65 \mathrm{~mW} / \mathrm{m}^{2}[6]$.

H. Tjiawi is with the Department of Civil and Environmental Engineering at National University of Singapore (phone: 65-91195144; email: hendrik.tjiawi@nus.edu.sg)

A. Palmer is with the Department of Civil and Environmental Engineering at National University of Singapore (email: ceepalme@nus.edu.sg)

G. J. H. Oliver is with the Department of Geography at National University of Singapore (email: geogo@ nus.edu.sg) 


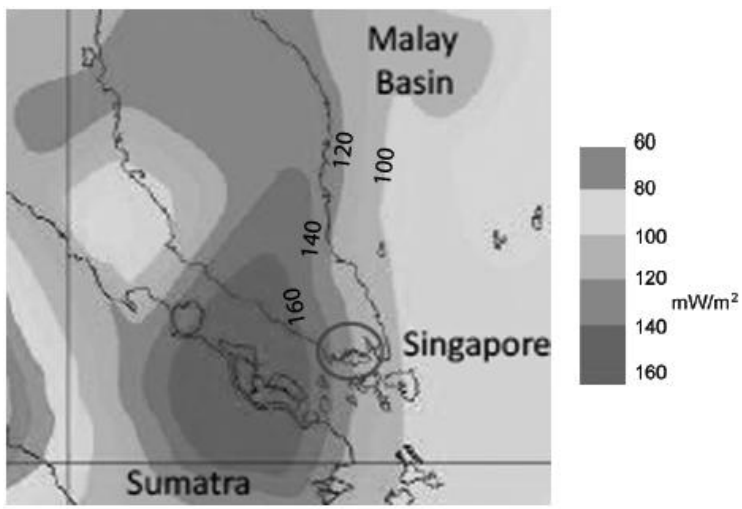

Figure 1 Heat flow contour map of part of SE Asia (modified from [5])

\section{Geological background}

Singapore has four main formations [7]: the igneous rock consisting of the Bukit Timah granite and the Gombak norite in the north, north east and the central north; the sedimentary rocks of the Jurong Formation in the west and southwest; the Quaternary deposits of the Old Alluvium in the east; and recent deposits of the Kallang Formation of the alluvium, transitional and marine clay throughout the island (Figure 2).

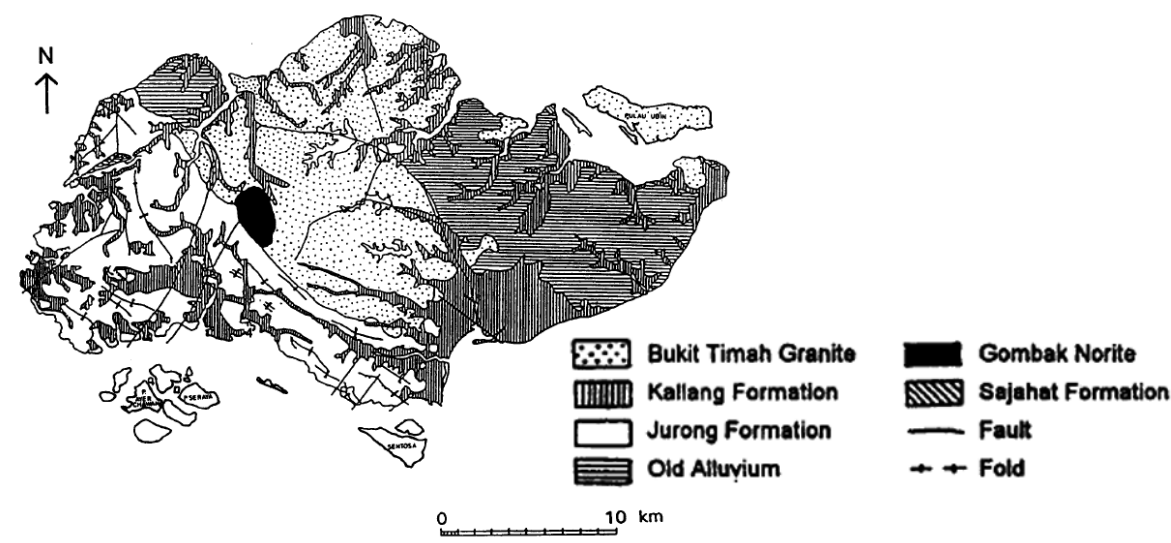

Figure 2 Simplified geological map of Singapore (modified from [8])

The full extent of the Bukit Timah granite is unknown, but the continuity of granite formation at the neighboring countries (Malaysia and Indonesia) suggests that the granite is the main rock formation underlying the whole Singapore Island. Zhao [9] recorded the hydraulic conductivity of the granite rock mass (within $\sim 100 \mathrm{~m}$ deep) is in order of $10^{-9}$ to $10^{-7} \mathrm{~m} / \mathrm{s}$ (or permeability of about $0.02 \mathrm{E}-15$ to $2 \mathrm{E}-15 \mathrm{~m}^{2}$ ).

The Jurong Formation consists of a wide variety of sedimentary rock, including conglomerate, sandstones, limestone and mudrocks. These rocks have a higher permeability than the Bukit Timah granite. The thickness of the Jurong Formation is unknown.

The alluvium formations are relatively shallow layers (up to $150 \mathrm{~m}$ ) covering both Eastern and Western part of Singapore Island.

\section{The hot springs}

Hot springs are one of the surface indicators for geothermal resource. There are three known hot springs in Singapore, i.e. 1 at Sembawang and 2 at Pulau Tekong, but only the Sembawang hot spring has been studied [10]. They are part of series of hot springs in the granite terrain of Malaysian Peninsula. Several wells have been drilled at the Sembawang site up to $100 \mathrm{~m}$ deep, encountering a $50 \mathrm{~m}$ wide water bearing fault, and discharging $70^{\circ} \mathrm{C}$ hot water with natural flow rate of $130 \mathrm{~L} / \mathrm{min}$ (or $2.1 \mathrm{~kg} / \mathrm{s}$ ). The pumped discharge is constant up to $460 \mathrm{~L} / \mathrm{min}$ by pumping for many days. Salinity of the hot spring is about $914 \mathrm{mg} / \mathrm{L}$, which is within the limit for drinking water set by PAHO [11].

\section{Other data}

Other input data include surface ground profile [12], rainfall distribution [13], seawater depth and salinity [14]. The highest point in Singapore is at the Bukit Timah hill $(164 \mathrm{~m})$. A cold spring at $120 \mathrm{~m}$ elevation is observed at the hill, suggesting the ground water level at least $120 \mathrm{~m}$ above sea level. 


\section{The groundwater model}

Oliver proposed a basic groundwater model for Singapore based on the USGS groundwater model for islands with unconfined aquifer surrounded by seawater [15]. The model uses the Gyben-Herzberg relation to estimate how deep the 120 $\mathrm{m}$ water level at Bukit Timah could drive the meteoric water down. This model assumes hydrostatic condition with rock permeability ignored. The model suggests that the $120 \mathrm{~m}$ head could drive the fresh water down to $4.8 \mathrm{~km}$ deep. At such a depth, the cold freshwater will be heated up and then flow up (due to density drop and volumetric expansion) to the surface as seen at the Sembawang hot spring.

\section{CONCEPTUAL MODEL}

The conceptual model can be constructed from the above data. It is a base model for the numerical simulation. A plan view (Figure 3a) is constructed from the known geological formation, location of Sembawang hot spring and the observed highest groundwater level (at $120 \mathrm{~m}$ asl). Also, Figure 3b shows a cross-section view along a SW-NE line passing through the Bukit Timah central catchment and the Sembawang hot spring. It is constructed from the geological formation, rainfall distribution, heat flow map, groundwater model, well testing data, surface contour, and seawater salinity.

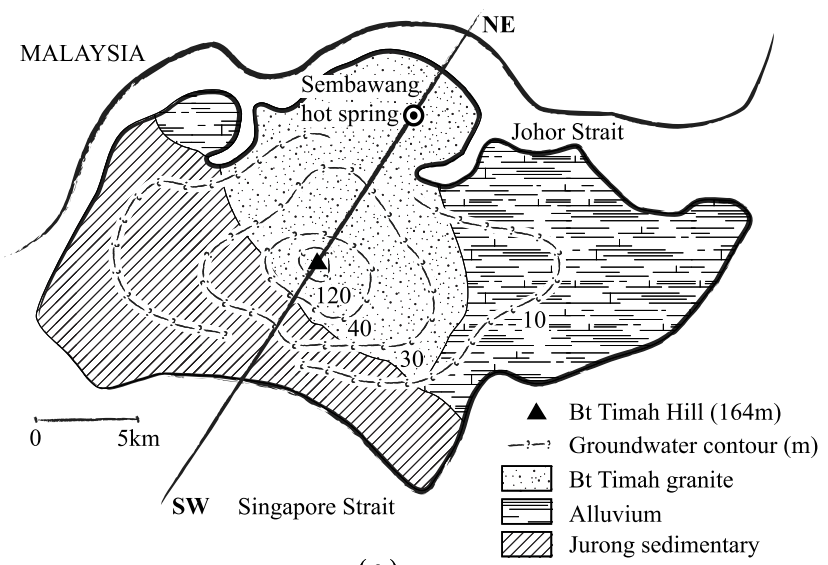

( a )

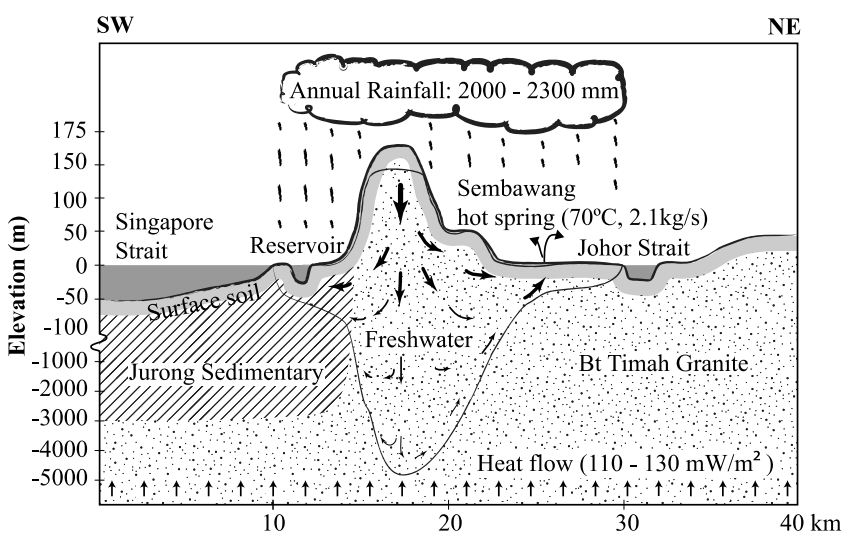

(b)

Figure 3 Conceptual model: (a) Plan view (b) SW-NE section view

In the conceptual model, the source of water for the Sembawang hot spring is from the recharge of groundwater from meteoric source through the $120 \mathrm{~m}$ hydraulic head at the Bukit Timah hill. Oliver constructed a rose diagram (based on fault and lineament trends from geology and satellite maps), and found that the diagram showed a SW-NE trend direction. This indicates that the jointed granite between the Central Catchment (at Bukit Timah) and the Sembawang hot spring ought to be fractured mostly in the SW-NE direction, and so the groundwater will flow preferentially in such direction.

\section{NUMERICAL SIMULATION}

The conceptual model is then discretized to allow for the numerical simulation with Auckland University version of TOUGH2 [16], i.e. the AUTOUGH2.2. Graphical pre- and post-processing are performed with MULGRAPH2.2 (developed by Auckland University).

The primary parameters for the simulation include the geometry of the grid, material properties (e.g. rock porosity, permeability, density, heat conductivity and heat capacity), salinity, temperature and pressure. The Equation of State (EOS) used is EWSG, which is the equation of state for non-isothermal mixtures of water/sodium chloride/non-condensible gas (e.g. air).

\section{Grid structure}

A 2D numerical model of porous type for the Singapore geothermal reservoir is constructed with overall horizontal dimension of $40 \mathrm{~km}$ and vertical dimension extends from $165 \mathrm{~m}$ above sea level to $6000 \mathrm{~m}$ below sea level (Figure 4). Structured rectangular cells are used to ensure convergence requirement of TOUGH2 is met. The horizontal sizes of the cell are larger $(1000 \mathrm{~m})$ for both NE and SW boundaries, and finer $(500 \mathrm{~m})$ for the main Singapore Island at the center portion. Vertically, the cell is the finest at near surface $(25 \mathrm{~m})$ to capture the surface contour, which affects the hydraulic head. The cell is coarser (up to $500 \mathrm{~m}$ ) as depth increases because fewer data are available for better details. The cell thickness is taken as $500 \mathrm{~m}$. The total number of the cells is 1972 . 


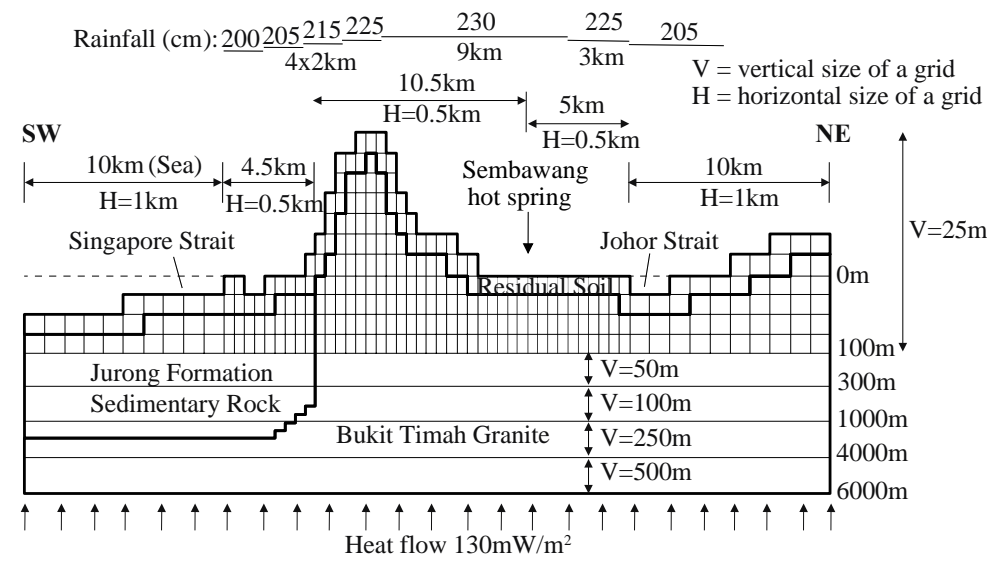

Figure 4 Size indicator map for the grid structure in 2D numerical simulation with AUTOUGH2.2

\section{Boundary conditions}

The boundary conditions are shown in Figure 5. Constant heat sources (represent heat flow) are generated at the bottom cells of the system. Heat sinks are provided in the form of very large volume and very low permeability cells attached to the top cells. These cells are referred to as 'atmospheric cells', and they are not graphically represented in Figure 5. The very large volume and very low permeability are to assure that they are thermodynamically constant, so that their temperature remains constant in the heat exchange process. Initial atmospheric temperature and pressure are assigned to these cells. The mass sources are assigned to the top cells, generating constant mass with atmospheric initial temperature to simulate the meteoric water. The atmospheric cells attached to the top cells at Singapore and Johor Straits are assigned with constant pressures (atmospheric pressure + hydrostatic pressures of seawater) and initial salinities to simulate the seawater.

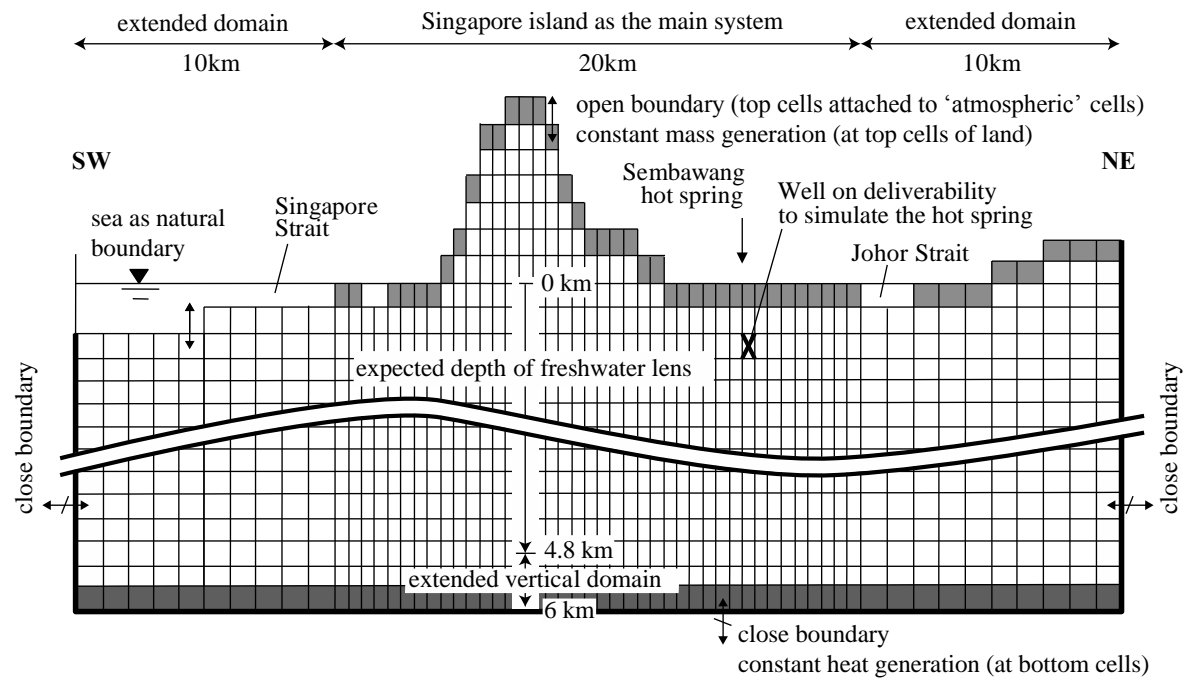

Figure 5 Boundary conditions of the model

For the mass sinks, since SW, NE and bottom boundaries are closed, the mass is only allowed to discharge to the atmospheric cells attached to the top cells, and to the well on deliverability (which simulates the Sembawang hot spring). The extended domain refers to extended boundaries. This is to assure that the model is self-contained and that its behavior is controlled by the mass structure alone, regardless of its lateral boundary conditions [17].

\section{Well on deliverability}

In TOUGH2 manual [16], well on deliverability is defined as production occurs against specified bottomhole pressure. This well is assigned to a grid near ground surface (Figure 5) to simulate the mass discharged at the Sembawang hot spring. Parameters used to simulate the well are the productivity index value and the corresponding bottomhole pressure. Productivity index (PI) for steady radial flow is given by [18]

$$
P I=\frac{2 \pi(k \Delta z)}{\ln \left(r_{e} / r_{w}\right)+s-1 / 2}
$$

where $r_{e}$ is the grid block radius (m) obtained from $\sqrt{\text { grid lateral area } \cdot \pi}, r_{w}$ is the well radius (m), $s$ is the skin factor (which is ignored for simplicity), and $k \Delta z$ is the permeability-thickness product $\left(\mathrm{m}^{3}\right)$ which is estimated from the pumping 
test pressure recovery graph (Figure 6). Semi-logarithmic well test analysis method [19] gives a relation of

$$
k \Delta z=\frac{2.303 q_{m} v}{4 \pi m}
$$

where $q_{m}$ is the mass flow rate $(\mathrm{kg} / \mathrm{s}), v$ is the kinematic viscosity of fluid $\left(\mathrm{m}^{2} / \mathrm{s}\right)$, and $m$ is the slope $(\mathrm{Pa} / \mathrm{log}$ cycle) in the semi-log plot of the pressure recovery in the pumping test (Figure 6). The pressure in the graph is taken relative to the hydrostatic pressure at feed zone level (estimated to be $45 \mathrm{~m}$ below ground surface).

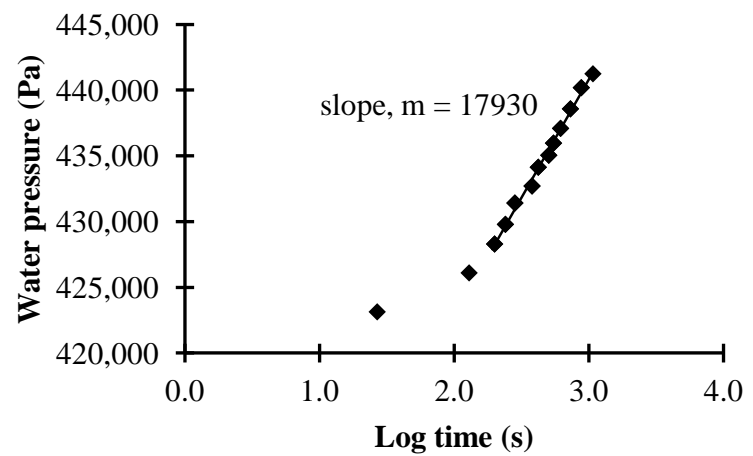

Figure 6 Semi-log plot of pressure recovery from a well pumping test (data from [10])

\section{Rock properties}

Figure 7 shows the cells with the rock names assigned to them. The estimated engineering properties of the rocks are given in Table 1.

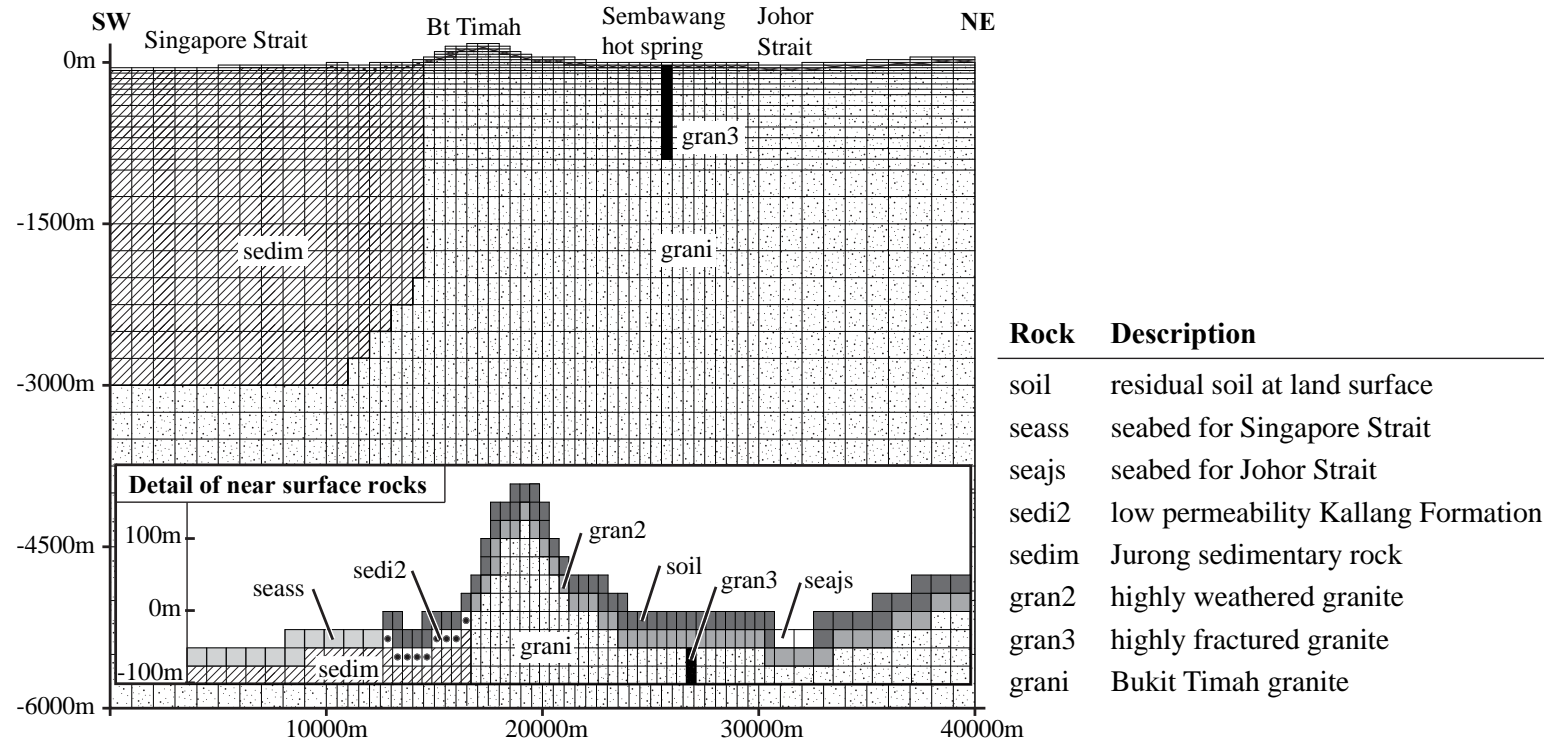

Figure 7 Generated grid blocks and the assigned rock types

Table 1 Rock properties used in the simulation (most values for granite are estimated from [20])

\begin{tabular}{cccccccc}
\hline $\begin{array}{c}\text { Rock } \\
\text { name }\end{array}$ & $\begin{array}{c}\text { Density } \\
\left(\mathrm{kg} / \mathrm{m}^{3}\right)\end{array}$ & Porosity & $\begin{array}{c}\text { Dry heat } \\
\text { conductivity } \\
(\mathrm{W} /(\mathrm{m} . \mathrm{K}))\end{array}$ & $\begin{array}{c}\text { Saturation } \\
\text { conductivity } \\
(\mathrm{W} /(\mathrm{m} . \mathrm{K}))\end{array}$ & $\begin{array}{c}\text { Specific heat } \\
\text { capacity } \\
\left(\mathrm{J} /\left(\mathrm{kg}{ }^{\circ} \mathrm{C}\right)\right)\end{array}$ & $\begin{array}{c}\text { Lateral } \\
\text { permeability } \\
\left(\mathrm{m}^{2}\right)\end{array}$ & $\begin{array}{c}\text { Vertical } \\
\text { permeability } \\
\left(\mathrm{m}^{2}\right)\end{array}$ \\
\hline soil & 2200 & 0.2 & 3.48 & 2.78 & 800 & $50 \mathrm{E}-15$ & $25 \mathrm{E}-15$ \\
gran2 & 2500 & 0.07 & 3.48 & 3.24 & 800 & $2.56 \mathrm{E}-15$ & $1.5 \mathrm{E}-15$ \\
gran3 & 2500 & 0.07 & 3.48 & 3.24 & 800 & $1000 \mathrm{E}-15$ & $1000 \mathrm{E}-15$ \\
grani & 2650 & 0.002 & 3.48 & 3.47 & $800^{\wedge}$ & $1.5 \mathrm{E}-15$ & $1 \mathrm{E}-15$ \\
sedi2 & 2200 & 0.07 & - & 2.5 & 1000 & $0.01 \mathrm{E}-15$ & $0.01 \mathrm{E}-15$ \\
sedim & 2400 & 0.05 & - & 2.5 & 1000 & $10 \mathrm{E}-15$ & $4 \mathrm{E}-15$ \\
seass & 2200 & 0.1 & - & 2.5 & 1000 & $0.75 \mathrm{E}-15$ & $0.75 \mathrm{E}-15$ \\
seajs & 2200 & 0.1 & - & 2.5 & 1000 & $0.05 \mathrm{E}-15$ & $0.05 \mathrm{E}-15$ \\
\hline
\end{tabular}

Note:

\# Saturation conductivity $=$ dry conductivity $(1-$ porosity $)$

$\wedge$ Estimated from [21] 


\section{Natural state calibration}

The natural state calibration is performed by running the simulation until a specified equilibrium is reached and there are no appreciable changes with time. The resulted groundwater, temperature and salinity profiles, and mass flow rate at the hot spring are compared with measured and/or expected field conditions (Figure 3b), and the permeability structure of the model is adjusted until a good match is obtained.

\section{Simulation results}

The main parameter to adjust is the rock permeability. In early simulation, the Bukit Timah granite ('grani' and 'gran2') vertical permeability is adjusted to (1-1.5)E-15 $\mathrm{m}^{2}$, and the mass recharge is adjusted to $2 \%$ of rainfall so that the expected groundwater level is approximately matched. The salinity profile is matched after adjusting the permeability of seabed sediment ('seajs' and 'seass'), Kallang Formation ('sedi2'), and Jurong Formation ('sedim'). To match the flow rate at the hot spring, permeability of 'gran3' is set to be very high to represent a highly fractured granite (perhaps the fault suggested in [10]). For the fault permeability estimation, Eq. 2 is used calculate $k \Delta z$. The fault thickness $(\Delta z)$ is estimated to be $10 \mathrm{~m}$, and so the corresponding permeability $(k)$ is in order of 1 Darcy (or $1000 \mathrm{E}-15 \mathrm{~m}^{2}$ ). If the fault thickness is lesser, its permeability will be higher. This permeability value is reasonable because fault is much more fractured than its original rock (i.e. Bukit Timah granite). Introducing this fault layer is necessary to obtain a concentratred outflow at the Sembawang hot spring. The adjusted permeability values for all rocks are given in Table 1.

The simulated water salinity at Sembawang hot spring is neither exactly fresh nor too saline (Figure 8a). The corresponding temperature profile, gives two upflows (Figure 8b): one main upflow at the Sembawang hot spring; and another towards the Jurong Formation. Groundwater flow (Figure 8c) shows upwards flow rate of $2.1 \mathrm{~kg} / \mathrm{s}$ at the Sembawang hot spring, which matches the measured natural flow rate of the hot spring.
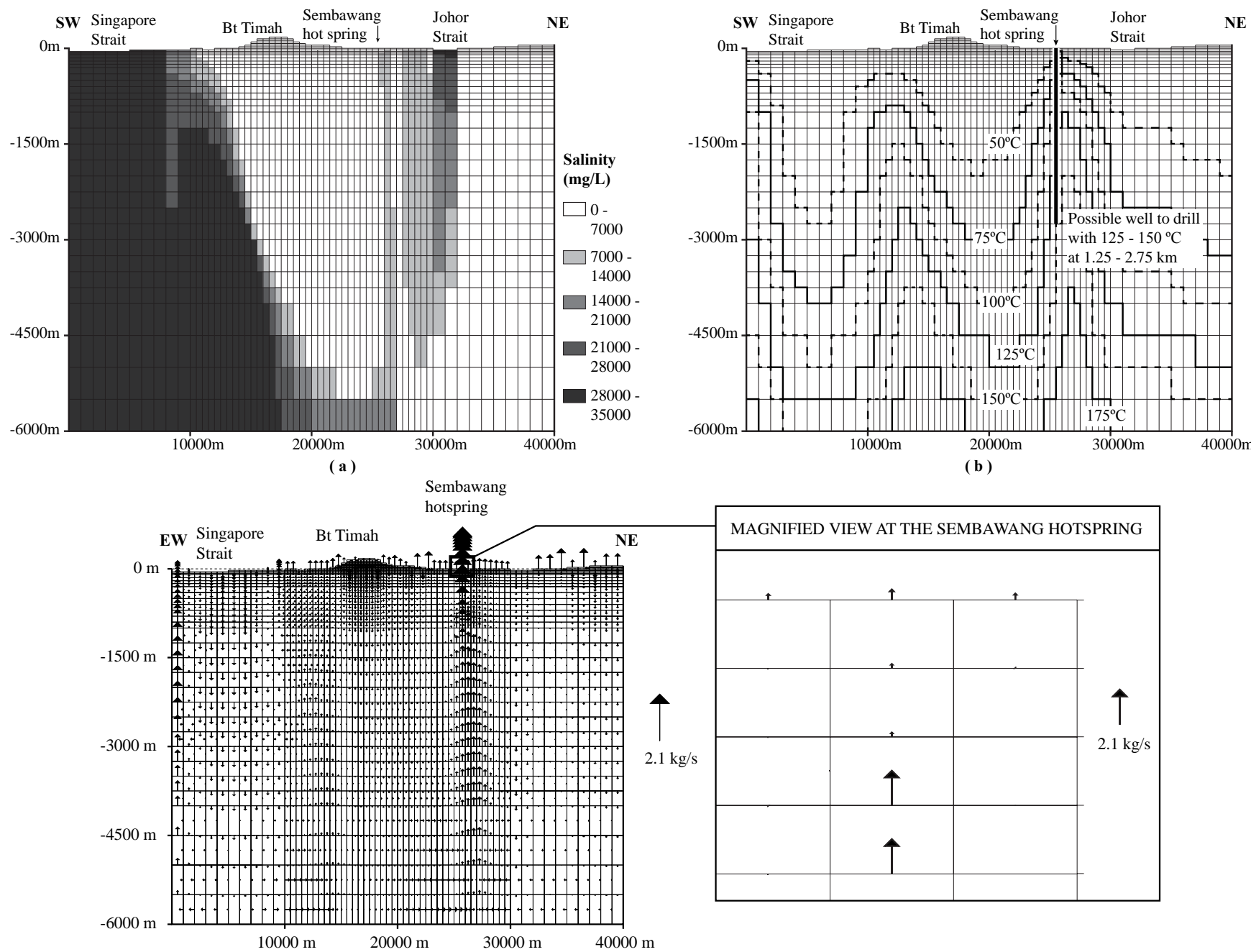

(c)

Figure 8 Simulation result: (a) Salinity profile (mg/L), (b) Temperature profile $\left({ }^{\circ} \mathrm{C}\right.$ ) with possible location of well to drill, and (c) Mass flow diagram showing upwards flow rate of $2.1 \mathrm{~kg} / \mathrm{s}$ at the hot spring 


\section{CONCLUSION}

Calibration for the natural state of Singapore geothermal reservoir has produced an encouraging result with temperature of $125-150{ }^{\circ} \mathrm{C}$ at relatively shallow depth of $1.25-2.75 \mathrm{~km}$.

\section{ACKNOWLEDGMENT}

This work is supported by ACrf Tier 1 grant R-264-000-275-133 from the Ministry of Education.

\section{REFERENCES}

[1] G. J. H. Oliver, "Geothermal energy concept for Singapore," SEAPEX Press, vol. 12, pp. 48-54, 2009.

[2] G. J. H. Oliver, A. C. Palmer, H. Tjiawi, and F. Zulkefli, "Engineered geothermal power systems for Singapore," The IES Journal Part A: Civil and Structural Engineering, vol. 4, pp. 245-253, November 20112011.

[3] F. Zulkefli, "Geothermal heat-driven district cooling system in a new housing estate feasibility study," B. Eng. unpublished thesis, Dept. of Civil and Env. Eng., National University of Singapore, Singapore, 2011.

[4] K. C. Ng. (2009, October). Adsorption desalination - An energy efficient sustainable technology. Engineering Research News [Online]. 24(3). Available: http://www.eng.nus.edu.sg/EResnews/0910/sf/sf8.html

[5] R. Hall and C. K. Morley, "Sundaland basins," Geophysical Monograph, vol. 149, pp. 55-85, 2004.

[6] H. N. Pollack, S. J. Hurter, and J. R. Johnson, "Heat flow from the Earth's interior: analysis of the global data set," Reviews of Geophysics, vol. 31, pp. 267-280, 1993.

[7] J. S. Sharma, J. Chu, and J. Zhao, "Geological and geotechnical features of Singapore: An overview," Tunnelling and Underground Space Technology, vol. 14, pp. 419-431, 1999.

[8] PWD, The Geology of the Republic of Singapore. Singapore: Public Works Department, 1976.

[9] J. Zhao, "Construction and utilization of rock caverns in Singapore - Part A: The Bukit Timah granite bedrock resource," Tunnelling and Underground Space Technology, vol. 11, pp. 65-72, 1996.

[10] J. Zhao, C. N. Chen, and J. G. Cai, "A hydrogeological study of the Sembawang hot spring in Singapore," Bulletin of Engineering Geology and the Environment, vol. 61, pp. 59-71, 2001.

[11] W. S. Chow, S. Irawan, and M. T. Fathaddin, "Hot springs in the Malay Peninsula," in Proceeding World Geothermal Congress 2010, Bali, Indonesia, 2010.

[12] C. L. Sien, H. Khan, and C. L. Ming, "The coastal environmental profile of Singapore," Technical Reports1988.

[13] E. S. Chan, P. Tkalich, K. Y.-H. Gin, and J. P. Obbard, "The physical oceanography of Singapore coastal waters and its implications for oil spills," in The Environment in Asia Pacific Harbours, E. Wolanski, Ed., ed: Springer Netherlands, 2006, pp. $393-412$.

[14] K. L. Ng and N. Sivasothi. (2001, 19 October 2010). Salinity and the mangroves ecosystem. Available: http://mangrove.nus.edu.sg/guidebooks/text/1011c.htm

[15] P. M. Barlow. (2003, 20 August 2011). Ground water in freshwater-saltwater environments of the Atlantic coast. [Online]. Available: http://pubs.usgs.gov/circ/2003/circ1262/ - heading156057192

[16] K. Pruess, C. M. Oldenburg, and G. J. Moridis, "TOUGH2 user's guide version 2.1," Lawrence Berkeley National Laboratory, California, Report LBNL-43134 (revised), 2011.

[17] M. J. O'Sullivan, K. Pruess, and M. J. Lippmann, "State of the art of geothermal reservoir simulation," Geothermics, vol. 30, pp. 395-429, 2001.

[18] K. H. Coats, "Geothermal Reservoir Modelling," presented at the 52nd SPE Annual Fall Technical Conference and Exhibition, Denver, Colorado, 1977.

[19] R. C. Earlougher, Jr., Advances in well test analysis. New York, Dallas: SPE, 1977.

[20] J. Zhao, B. Broms, Y. Zhou, and V. Choa, "A study of the weathering of the Bukit Timah granite - Part B: Field and laboratory investigations," Bulletin of Engineering Geology and the Environment, vol. 50, pp. 105-111, 1994.

[21] W. J. Cho and S. Kwon, "Estimation of the thermal properties for partially saturated granite," Engineering Geology, vol. 115, pp. $132-138,2010$. 